\title{
Fuel poverty in the UK: beyond heating?
}

\author{
Neil Simcock ${ }^{1 *}$, Gordon Walker², Rosie Day³ \\ 1 University of Manchester \\ 2 Lancaster University \\ 3 University of Birmingham
}

\begin{abstract}
Fuel poverty is now widely recognised in the UK as a distinct form of social inequality and injustice, but exactly which energy-uses and services should be incorporated into conceptualisations of fuel poverty is rarely discussed explicitly. In this paper, we investigate how different energy-uses are portrayed as part of fuel poverty by national government and NGOs in the UK. We find that, to some degree, official definitions of fuel poverty in the UK include multiple energy-uses. However, this is not reflected in dominant policy and NGO discourses which predominantly frame fuel poverty as solely a lack of adequate space-heating. We conclude by discussing whether non-heating energy-uses and services should be more fully recognised and incorporated into fuel poverty discourses and policy measures, identifying two areas that warrant further research and debate.
\end{abstract}

Key words: Fuel poverty; heating; needs; energy.

\section{Introduction}

Fuel poverty is now widely recognised in the UK as a distinct form of social inequality and injustice (Roberts, 2008; Walker and Day, 2012). Over recent decades, a variety of policies have been proposed and implemented with the aim of addressing the problem (Sovacool, 2015), and the most appropriate way of defining fuel poverty has also been subject to some recent scrutiny (Hills, 2011, 2012). In such debates, however, a fundamental question has received little attention: what energy-uses or services should be included in conceptualisations of what it means to be in 'fuel poverty'? The aim of this paper is to begin to open this question up to further debate.

Much of the UK academic literature on fuel poverty treats space heating as the sole or predominant energy service of concern. The notions of 'affordable warmth' or cold homes have long been a central focus, from the early work of Bradshaw (1983) and Boardman (1991) up to more recent articles (e.g. Anderson et al., 2012; Christman and Russell, in press; Walker and Day, 2012; Middlemiss, 2015). The negative health impacts of living at cold temperatures have also been widely examined (Boardman, 1991, 2010; Ormandy and Ezratty, 2012), including fuel poverty's relation to the problem of 'excess winter deaths' (Liddell and Morris, 2010). The 2012 Fuel Poverty 
Review (Hills, 2011; 2012) is the most substantial examination of the meaning and definition of fuel poverty in recent times, but this too largely represents fuel poverty as fundamentally about people's ability to keep warm (Simcock and Walker, 2015). The UK approach has been very influential elsewhere, and so there is a tendency for research in some other developed countries to also portray fuel poverty - often termed 'energy poverty' in these literatures - as an inability to afford adequate space heating (e.g. Dubois, 2012; Harrison and Popke, 2011; Viggers et al., 2013).

However, more recently a small body of conceptual work has argued that, fundamentally, fuel poverty is an inability to attain sufficient levels of 'essential' energy services (Bouzarovski and Petrova, 2015; Day and Walker, 2014). Under these broader conceptualisations, the 'essential energy services' required to avoid fuel poverty and have a decent quality of life may include, but are not necessarily limited to, space heating. Following this reasoning, it is important to note that in the UK, whilst sufficient heating remains vitally important, many other energy-uses are deeply entwined in everyday domestic life. Studies suggest, for example, that non-heating energy-uses on average comprise 38 per cent of household energy consumption and costs (Palmer and Cooper, 2013). Consumption from some electrical appliances has been rising for several years, particularly consumer electronics, home computing, and appliances (Energy Saving Trust, 2011), with these items taking up an increasing proportion of overall household energy consumption on average (Department of Energy and Climate Change (DECC), 2015a). Recent research also finds that the UK public considers several non-heating domestic energy-uses to be 'basic necessities' required for a minimum acceptable living standard (Bradshaw et al., 2008; Davis et al., 2014).

With these dynamics in mind, this paper analyses the extent to which energy-uses other than heating figure at all in the definitions and discourses of fuel poverty found in national policy and in the work of non-governmental organisations (NGOs). Therefore, we investigate whether these actors reflect the dominant academic portrayal of fuel poverty as a lack of sufficient heating and warmth. We begin by explaining the methods through which evidence has been collated, before outlining the findings of our analysis. We conclude by discussing the implications of our study for research and policy.

\section{Methods}

\section{Analysis of policy documents}

A central part of our research involved examining the 'official' definitions of fuel poverty used in policy. Definitions matter because they influence both how the condition of fuel poverty is understood (what fuel poverty 'is'), and, in the case of 'official' policy definitions, how it is measured and represented in statistics (Hills, 2012; Moore, 2012). Upon identifying official definitions that have been used by the UK government, we examined whether and how these explicitly or implicitly include non-heating energyuses. This included unpacking the fuel poverty statistics methodology, which is used to generate estimates of the prevalence of fuel poverty in the UK.

Following this, we then examined the extent to which different energy-uses are recognised in wider policy discussion of fuel poverty, recognising that fuel poverty discourse extends beyond merely definitions (although definitions are of course interlinked with wider discourse). Our underpinning assumption here is that discourse acts as a key medium through which knowledge circulates, thus shaping how issues are understood, defined and addressed (Fairclough, 1992). Our data sources for this analysis were eight national policy documents (further details are given in Table 1) consisting of: 
- The six most recent DECC fuel poverty documents that have been published following the 2011-2012 Fuel Poverty Review (hereafter the 'Hills Review'), including the first new fuel poverty strategy for 14 years that was published in 2015.

- The Warm Homes and Energy Conservation Act (WHECA) 2000 and the 2001 UK Fuel Poverty Strategy. Together, these documents enabled us to gain a sense of any temporal change.

Analysis involved, first, a quantitative content analysis of the number of times specific words - relating to both space-heating and non-space-heating energy-uses occurred in policy documents. ${ }^{1}$ The non-heating energy-uses searched for were those that are incorporated in the government's fuel poverty statistics methodology (cooking, lighting, appliances and hot water), alongside mentions of 'fridge', 'television', or 'computer' on the basis that these are both widely-owned and have been defined in recent research as 'basic necessities' by members of the UK public (Davis et al., 2014). Word frequency was counted using document search functions, and when possible multiple words were used to search for a single energy-use in order to minimise the impact that writing style may have on the results.

Following this quantitative stage, a qualitative content analysis was conducted of these policy documents, informed by a 'framing analysis' approach (Entman, 1993). This involved careful analytical reading of the documents, aiming to capture how different energy-uses were portrayed and discussed.

Table 1: The policy documents analysed

\begin{tabular}{|l|l|l|l|}
\hline Document name & $\begin{array}{l}\text { Author and year } \\
\text { published }\end{array}$ & Document type & $\begin{array}{l}\text { Number of } \\
\text { pages }\end{array}$ \\
\hline 2000 WHECA & 2000 & Act of Parliament & 3 \\
\hline 2001 Strategy & DTI (2001) & Strategy & 158 \\
\hline $\begin{array}{l}\text { Fuel poverty: changing the } \\
\text { framework for measurement }\end{array}$ & DECC (2012) & Consultation & 53 \\
\hline $\begin{array}{l}\text { Fuel poverty: changing the } \\
\text { framework for measurement }\end{array}$ & DECC (2013) & $\begin{array}{l}\text { Government } \\
\text { response to } \\
\text { consultation }\end{array}$ & 21 \\
\hline $\begin{array}{l}\text { Fuel Poverty: A framework } \\
\text { for future action }\end{array}$ & DECC (2013) & Framework & 48 \\
\hline $\begin{array}{l}\text { Cutting the costs of keeping } \\
\text { warm: } \text { A new fuel poverty } \\
\text { strategy for England }\end{array}$ & DECC (2014) & Consultation & 78 \\
\hline $\begin{array}{l}\text { Cutting the costs of keeping } \\
\text { warm: } \text { A new fuel poverty } \\
\text { strategy for England }\end{array}$ & DECC (2015) & $\begin{array}{l}\text { Government } \\
\text { response to } \\
\text { consultation }\end{array}$ & 39 \\
\hline $\begin{array}{l}\text { Cutting the costs of keeping } \\
\text { warm: } \text { A new fuel poverty } \\
\text { strategy for England }\end{array}$ & DECC (2015) & Strategy & 81 \\
\hline
\end{tabular}

\section{Analysis of national fuel poverty NGO websites}

Whilst the study of policy definitions and discourse is the central part of our research, we also examined nine national fuel poverty NGOs and campaign groups (Table 2). These were selected for specific investigation because they are an important 


\section{p. 28. Fuel poverty in the UK: beyond heating?}

and influential part of the fuel poverty discourse landscape in the UK, helping to shape how the issue is understood and talked about. For example, they often contribute to government consultations, including the influential Hills Review, and are frequently quoted in news media reporting.

Table 2: The fuel poverty NGOs and campaign groups studied

\begin{tabular}{|l|l|}
\hline $\begin{array}{l}\text { Organisation or } \\
\text { campaign }\end{array}$ & Description \\
\hline $\begin{array}{l}\text { National Energy } \\
\text { Action }\end{array}$ & $\begin{array}{l}\text { A national charity that researches, campaigns and works to } \\
\text { eradicate fuel poverty. }\end{array}$ \\
\hline $\begin{array}{l}\text { Centre for } \\
\text { Sustainable Energy }\end{array}$ & $\begin{array}{l}\text { A national charity that researches and manages projects on various } \\
\text { aspects of sustainable energy, including fuel poverty. }\end{array}$ \\
\hline Citizen's Advice & $\begin{array}{l}\text { A national charity that provides free and independent advice to } \\
\text { everyone on their rights and responsibilities. }\end{array}$ \\
\hline $\begin{array}{l}\text { Association for the } \\
\text { Energy }\end{array}$ & $\begin{array}{l}\text { A UK organisation that promotes energy efficiency and } \\
\text { conservation, it represents the energy conservation industry. }\end{array}$ \\
\hline Age UK & $\begin{array}{l}\text { A national charity that aims to support older people in living a full, } \\
\text { active and healthy life. }\end{array}$ \\
\hline $\begin{array}{l}\text { National Right to Fuel } \\
\text { Campaign }\end{array}$ & $\begin{array}{l}\text { An independent and volunteer-led campaign which brings together } \\
\text { a range of voices from the corporate, charitable and public sectors } \\
\text { to raise the profile of fuel poverty. }\end{array}$ \\
\hline Fuel Poverty Action & $\begin{array}{l}\text { A campaign group made up ordinary citizens, with aim of } \\
\text { eradicating fuel poverty and promoting renewable energy. }\end{array}$ \\
\hline $\begin{array}{l}\text { Energy Bill Revolution } \\
\text { Coalition }\end{array}$ & $\begin{array}{l}\text { A public alliance, made up of children's and older people's } \\
\text { charities, environment groups, health and disability groups, trade } \\
\text { unions, consumer groups, businesses, politicians and public } \\
\text { figures. Calls for warm homes and lower bills for all. }\end{array}$ \\
$\begin{array}{l}\text { Campaign group made up of made up of poverty, environmental, } \\
\text { health, trade union and consumer organisations. Calls for the } \\
\text { eradication of fuel poverty and the nationwide roll-out of energy } \\
\text { efficiency. }\end{array}$ \\
\hline
\end{tabular}

Our particular data source for this stage of the analysis was the websites of these nine NGOs. We systematically searched these websites and conducted a qualitative analysis of how they described fuel poverty, with a particular focus on whether and how different energy-uses were discussed and represented.

\section{Non-heating energy-uses in UK government fuel poverty definitions and wider discourses}

\section{Government definitions}

Prior to 2001, there was no 'official' government or policy definition of fuel poverty. The Conservative government of the 1980s and 90s did not consider 'fuel poverty' to be a recognisable phenomenon and avoided using the term, although they did occasionally refer to the importance of households having 'affordable warmth' (Boardman, 2010). The first national definition was developed in the Warm Homes and Energy 
Conservation Act (WHECA) 2000, which stated that 'a person is to be regarded as living "in fuel poverty" if he is a member of a household living on a lower income in a home which cannot be kept warm at reasonable cost' (p.1, emphasis added). The focus of this definition is thus solely on heating and people's ability to keep warm.

In The UK Fuel Poverty Strategy 2001, a slightly different definition was developed, partly because of the need to have a more quantifiable version that could be operationalised in annual modelling to estimate the number of UK residents living in fuel poverty. This was subsequently adopted as the 'official' fuel poverty definition by all four nations of the UK (Scotland, Wales, Northern Ireland and England), and is as follows:

A household is in fuel poverty if, in order to maintain a satisfactory heating regime, it would be required to spend more than 10\% of its income (including Housing Benefit or Income Support or Mortgage Interest) on all household fuel use. (Defra \& DTI, 2001, p.30, emphasis added)

In this definition, alongside consumption for heating, energy consumed for other non-heating purposes is incorporated - although a prescriptive list of particular services considered essential is not provided, non-heating uses are incorporated under the umbrella of 'all household fuel use'. However, it is also notable that the ability to maintain a 'satisfactory heating regime' is specifically highlighted as the end goal that the household should be able to achieve, suggesting that this is the primary underpinning concern.

Following the Energy Act 2013, and informed by recommendations made by the Hills Review, a new official definition of fuel poverty was adopted in England (other UK nations maintained the ' 10 per cent' definition). Termed the 'Low Income High Costs' (LIHC) indicator, it states that a household is in fuel poverty if:

- They have required fuel costs that are above average (the national median level).

- Were they to spend that amount, they would be left with a residual income below the official poverty line. (DECC, 2013a).

Here, reference is made to 'required fuel costs', but exactly which energy-uses are included under this umbrella is unspecified - in this regard, the LIHC definition is less clear than the ' 10 per cent' version, which explicitly referred to 'all household fuel use.' Although the phrase 'required fuel costs' could be read as indicating the cost of all energy-uses, it would also make sense if referring only to heating costs. Only by reading more deeply into DECC's (2014) Fuel Poverty Statistics Methodology and User Manual does it become clear that, when operationalised during the generation of annual fuel poverty statistics (which estimate the prevalence of fuel poverty in the UK), the LIHC definition still incorporates several non-heating energy-uses. These statistics are produced through a modelling process that generates estimates for three core elements - household income, energy prices, and the amount of energy consumption (kWh) 'required' by each modelled household - which are then amalgamated to produce estimates of the prevalence of fuel poverty (Simcock and Walker, 2015). The calculations of households' 'required' energy consumption takes account of several non-heating energy-uses, with separate calculations to estimate the consumption needed for lighting, hot water, cooking, and the generic category of 'appliances' (Henderson and Hart, 2013). Indeed, approximately 56 per cent of the mean modelled household fuel bill goes toward space heating, whilst the remaining 44 per cent goes toward non-heating consumption (DECC, 2014). Thus, non-heating energy-uses are included and, on average, make up a significant portion of the total 'required' energy 


\section{p. 30. Fuel poverty in the UK: beyond heating?}

use. The same underpinning model has been used to calculate these elements for both the new LIHC fuel poverty definition and the older 10 per cent indicator, so although the wording of these two definitions has changed, the underlying model has not. Further discussion on how this modelling process works, and its underlying assumptions and principles, can be found in Simcock and Walker (2015) and Walker et al. (2015).

\section{Wider policy discourse}

Table 3 presents results from our quantitative content analysis of the six most recent DECC fuel poverty reports. It demonstrates a stark difference in the number of mentions of space heating compared to various non-heating energy-uses - references to heating are substantially greater, with 699 total mentions compared to only 21 for all non-heating uses combined. This disparity is evident in all six documents, with two making no mention of any non-heating services at all, whilst one only refers unspecifically to 'appliances'. There is no mention of fridges, televisions, or computers in any of the documents. 
p. 31. Fuel poverty in the UK: beyond heating?

Table 3: Number of mentions of different energy-uses in DECC policy documents

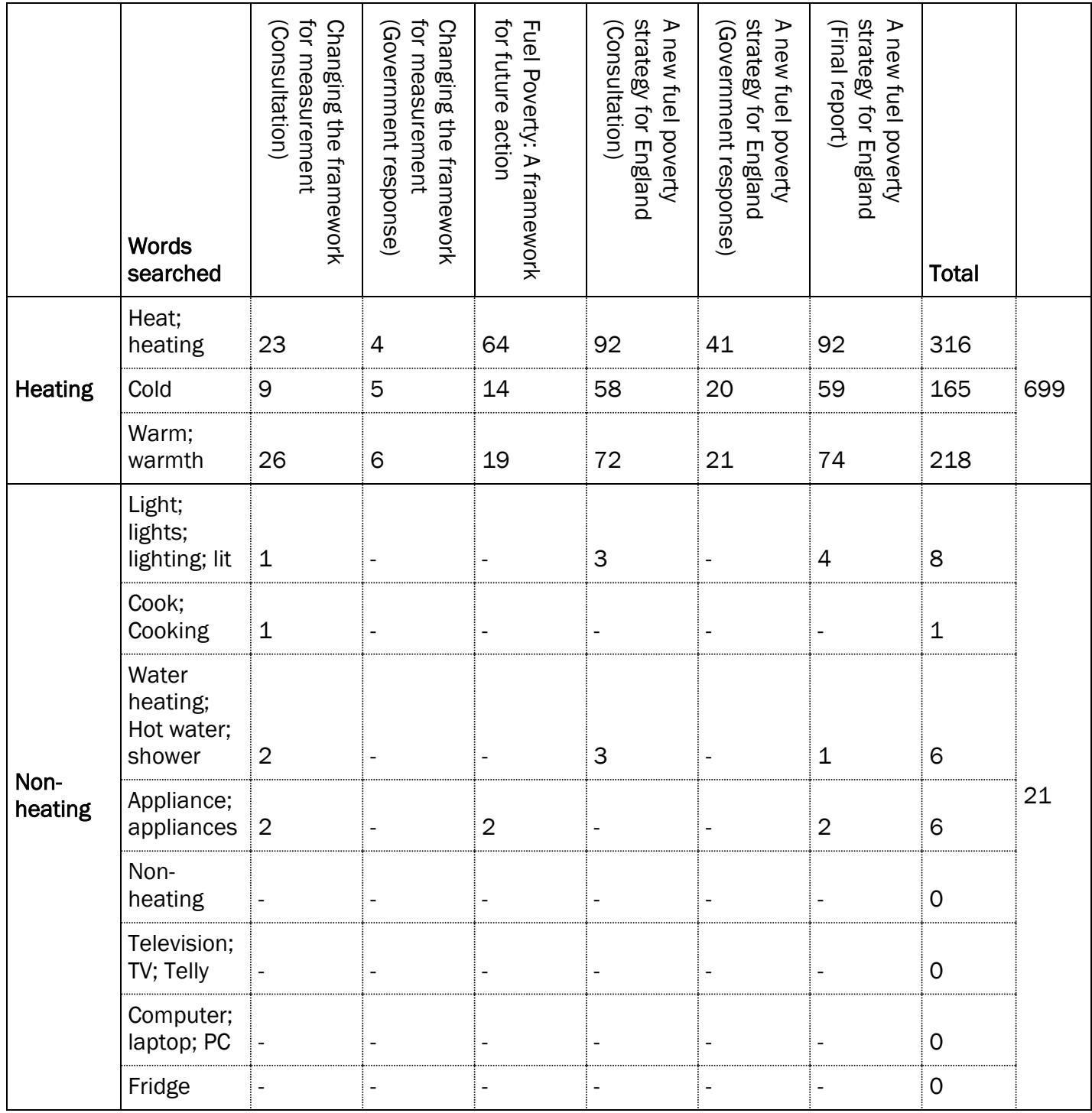

A qualitative content analysis further evidence that these documents overwhelmingly emphasise heating and warmth as the core concerns of fuel poverty. Indeed, the title alone of the 2015 Fuel Poverty Strategy, Cutting the Costs of Keeping Warm, makes this very clear. This document then opens with a ministerial Foreword stating:

I still find it extraordinary in the 21st century that so many homes in our country are so expensive to heat and run. It represents a huge policy failure of past Governments going back decades that so many people live in cold, leaky homes. We need to get to grips with this problem once and for all, so people don't have to pay such large electricity and gas bills, so people's health doesn't suffer from lack of warmth and so we aren't making climate change worse as our fellow citizens shiver. (DECC, 2015b, p.6, emphasis added) 


\section{p. 32. Fuel poverty in the UK: beyond heating?}

Similarly, the opening sentence of DECC's (2013b) 'Fuel Poverty: a Framework for Future Action' document states that 'Ensuring that people are able to keep warm in their homes is a priority for this Government' (p.7). It is important to note that both these examples are from opening statements, because 'introductions' are crucial elements in framing the topic and underpinning assumptions of a text (Fairclough, 1992). Although, as shown in our above analysis, official definitions of fuel poverty do incorporate non-heating energy-uses (either implicitly or explicitly), this is not reflected or even widely acknowledged in recent policy discussion.

The one slight exception to this rule is the 2001 UK Fuel Poverty Strategy. In total, this document has 24 mentions of non-heating energy-uses; slightly more than the combined total of the six recent DECC documents (despite having 162 fewer pages). However, as Table 4 shows, the document's 385 references to heating are still substantially greater than mentions of non-heating uses.

Table 4: Number of mentions of different energy-uses in 2001 Fuel Poverty Strategy

\begin{tabular}{|c|c|c|c|}
\hline & Words searched & Total & \\
\hline \multirow{3}{*}{ Heating } & Heat; heating & 193 & \multirow{3}{*}{385} \\
\hline & Cold & 63 & \\
\hline & Warm; warmth & 129 & \\
\hline \multirow{8}{*}{$\begin{array}{l}\text { Non- } \\
\text { heating }\end{array}$} & Light; lights; lighting; lit & 3 & \multirow{8}{*}{24} \\
\hline & Cook; Cooking & 5 & \\
\hline & Water heating; Hot water; shower & 6 & \\
\hline & Appliance; appliances & 7 & \\
\hline & Non-heating & 3 & \\
\hline & Television; TV; Telly & - & \\
\hline & Computer; laptop; PC & - & \\
\hline & Fridge & - & \\
\hline
\end{tabular}

At particular points in the strategy (p.30 and p.107), non-heating uses are discussed in some detail - indeed, at these points the document explicitly questions whether definitions of fuel poverty should centre solely on heating, or should also include other energy-uses. It is noted that, following discussions, ministers ultimately decided that non-heating uses should be incorporated - hence the government's subsequent '10 per cent' definition referencing 'all energy uses' (see section above 'Government definitions'). The Strategy provides two explanations for this decision. The first is that 'no worthwhile distinction can be made between fuel used for heating and hot water and that for other, equally essential purposes' (Defra \& DTI, 2001, p.30). The second is that 'Fuel use for lighting and cooking purposes could also be considered as essential use ... It was therefore decided that the definition of fuel poverty should be based on all household expenditure on fuel, including that used for non-heating purposes' (ibid. p.107). Therefore, in the 2001 Strategy the question of 'what energyuses matter?' briefly emerged as an issue for debate, before largely disappearing in subsequent documents and their portrayal of fuel poverty. That said, even these two explanations are rather vague and lack any substantial rationale. Whilst it is stated that non-heating uses are 'essential', no reasons or evidence are provided for why this might be so. In contrast, two-pages of the report are dedicated to discussing why adequate space-heating is a basic necessity, with detailed rationales relating to ill 
health and social exclusion. Moreover, since cooking, lighting and hot water are the only services specifically identified as essential, it is not clear why all non-heating energy-uses were eventually incorporated into the '10 per cent' definition of fuel poverty that emerged from this strategy.

\section{Non-heating energy-uses in fuel poverty definitions and wider discourses of national NGOs}

\section{NGO definitions}

Many of the NGOs that we studied did not contain a specific definition of fuel poverty on their websites - of the nine organisations we examined, only two offered definitions of fuel poverty. The first was National Energy Action (NEA), ${ }^{2}$ who utilise a definition that is very similar to the official ' 10 per cent' version:

Fuel poverty is defined as the need to spend more than $10 \%$ of household income on fuel costs to maintain adequate warmth for health and comfort. (Emphasis added)

Unlike the official definition, NEA's version makes no specific mention of 'all energy use', and the section 'fuel costs to maintain adequate warmth' could suggest that only space heating is incorporated. However, in the light of the official version, it could also be read as incorporating other energy-uses under the 'fuel costs' umbrella. In this regard the definition is somewhat ambiguous, although the specific mention of 'adequate warmth' suggests that heating is especially important - similar to the mention of a 'satisfactory heating regime' in the official '10 per cent' definition.

The second NGO definition comes from the National Right to Fuel Campaign (NRFC):

A situation where a household spends $10 \%$ or more of its overall income, on sufficiently lighting and heating a home to $21^{\circ} \mathrm{C}$ in the living room and to $18{ }^{\circ} \mathrm{C}$ in all other rooms. (emphasis added)

This definition is interesting because it explicitly incorporates sufficient lighting alongside adequate space-heating. In this respect, it is less vague in its inclusion of a non-heating energy-use than other definitions, but is also narrower in excluding uses beyond heating and lighting. It is interesting to note that the group has not always included lighting as part of its definition - their early 1982 definition specifically and only encompasses domestic space heating: '[T]he inability to afford adequate warmth at home. It arises when low income is combined with high heating costs' (National Right to Fuel Campaign, 1982, cited in Bradshaw and Harris, 1983). There has thus been some evolution in how they define fuel poverty, with at least one non-heating energy service now openly recognized.

\section{Wider NGO discourse}

As with the discourses of the policy documents (see above section on 'Wider policy discourse'), on the vast majority of NGO and campaign group websites the dominant representation of fuel poverty is as an issue of affordable space-heating and people's ability to achieve sufficient thermal comfort. For example, Figure 1 below, from the homepage of the 'Energy Bill Revolution' - a campaign group that aims to 'end the fuel poverty crisis once and for all' - powerfully conveys an emphasis on ensuring adequate warmth and home heating. Indeed, even the term 'fuel poverty' is itself used sparingly 
on the site, with language use centring on phrases such as 'cold homes' or 'affordable warmth.'

Figure 1: The homepage of the Energy Bill Revolution website
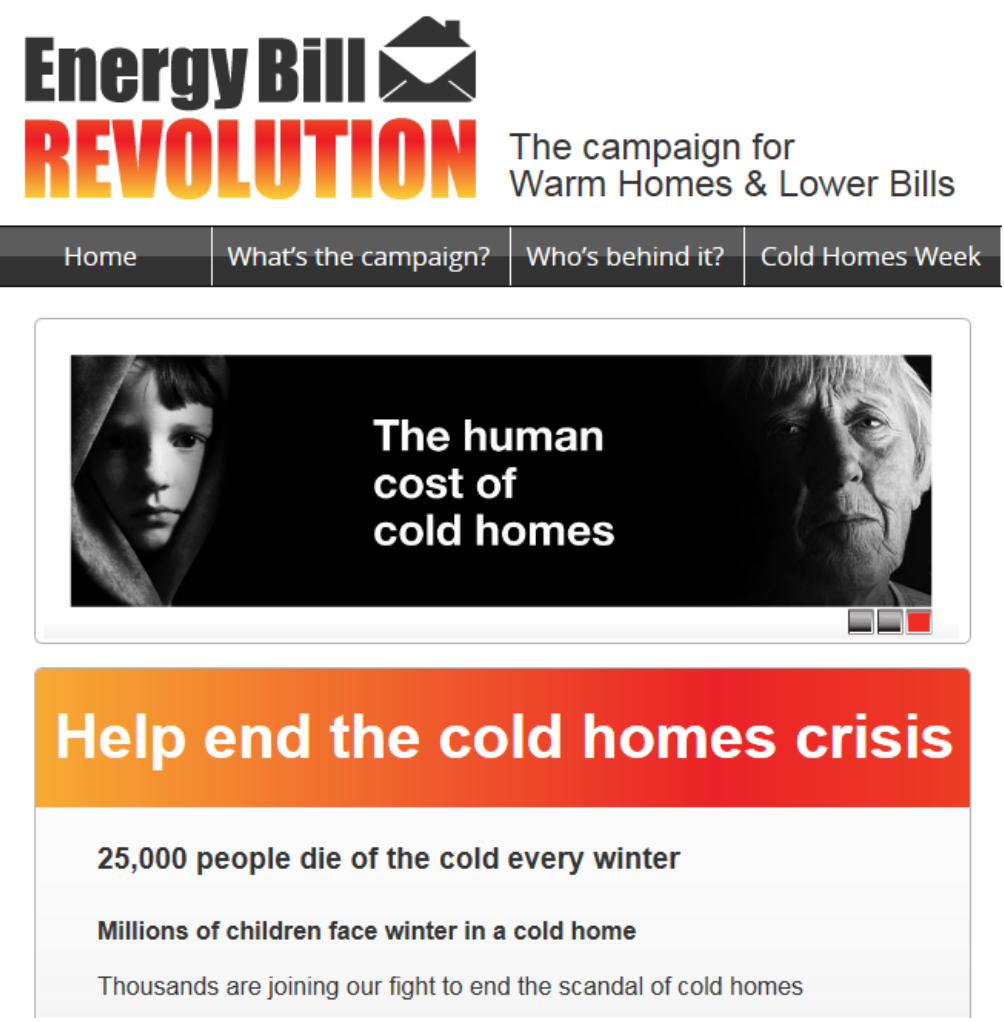

Likewise, the homepage for NEA contains the group's logo accompanied by their slogan 'Action for Warm Homes', and by following the 'Campaigns \& Events' link at the top of the page readers are directed to the group's 'Warm Homes Campaign'. This emphasis on space-heating is consistent with the group's stated definition of fuel poverty, which makes explicit mention of 'adequate warmth'. In comparison, across almost all websites non-heating energy services are barely mentioned, and when they are it is often with somewhat vague, unspecific references such as 'other energy services' (Centre for Sustainable Energy), 'affordable energy' (Fuel Poverty Action) or 'power' (End Fuel Poverty). Table 5 provides a set of example quotes that demonstrate the space-heating emphasis of these websites. 
Table 5: Quotes demonstrating the emphasis on space-heating on the websites of fuel poverty NGOs and campaign groups

\begin{tabular}{ll}
$\begin{array}{l}\text { Organisation or } \\
\text { campaign }\end{array}$ & Example quotes \\
\hline Age UK & $\begin{array}{l}\text { "Fuel poverty has become increasingly prominent in recent years. Although } \\
\text { all households have felt the impact of increasing energy prices, it is } \\
\text { pensioners who have borne the hardest brunt of fuel poverty. Research } \\
\text { commissioned by Age Concern and Help the Aged in Scotland showed that } \\
\text { in March 2009 almost a third of people aged 55 or over had turned down } \\
\text { their heating in the past six months due to concerns about the cost." }\end{array}$ \\
$\begin{array}{ll}\text { Association for } \\
\text { the }\end{array}$ & $\begin{array}{l}\text { "Chilled to death": the human cost of cold homes' } \\
\text { Energy }\end{array}$ \\
\hline
\end{tabular}

Centre for

Sustainable

'A persistently cold home causes misery, ill-health and social exclusion.

Energy Currently more than 5 million households in the UK can't afford to keep adequately warm in winter, often as a result of poor insulation standards and inefficient heating in their homes. Ensuring people are meeting their needs for affordable warmth and other energy services is fundamental to CSE's understanding of sustainable energy. Which is why tackling fuel poverty is one of our core objectives and a feature of many of our projects.'

Citizen's Advice ‘Urgent action is needed for millions of households across the country to eradicate fuel poverty. The Government is right to put a marker down to make homes warmer. Citizens Advice wants to see greater ambition to improve properties more quickly so that people can afford to heat their homes.'

\begin{tabular}{ll}
\hline End Fuel & 'We believe everybody in this country has the right to a warm, dry home \\
Poverty & that they can afford to heat and power. Action to end fuel poverty will not \\
Coalition & only improve people's lives but also help tackle climate change'
\end{tabular}

Energy Bill 'We are facing an energy bill crisis, with millions of people struggling to Revolution heat their homes. One of the main causes is that the UK's homes are some of the least energy efficient in Europe - leaking heat from their doors, walls and windows. As a result energy bills are high and fuel poverty is getting worse. On average 25,000 people die of the cold each year and at least a third of these deaths are due to living in cold homes. That means that every year four times more people die from living in cold homes than die on British roads. Cold homes cost the NHS $£ 1$.3bn every year.'

Fuel Poverty 'Fuel Poverty Action campaigns against the injustice of cold homes by Action turning up the heat on rip-off energy companies and the politicians in their pockets. We take action for warm, well insulated homes and clean and affordable energy, under the control of people and communities, not private companies'

National Energy 'Living in fuel poverty means being unable to afford to heat your home to a Action comfortable and healthy level. It means turning off the heating even though you are ill and it's freezing outside because you are terrified of falling into debt. It means going without food for two days so you can top up your pre-payment meter to keep the house warm for your children. And it means that what should be a basic human right to live in a warm dry home, is in fact for many, an increasingly unachievable aspiration.' 
The one exception to this overriding emphasis on heating is, again, the National Right to Fuel Campaign (NRFC). As noted, the group's definition of fuel poverty states that households require 'sufficient lighting' to be free of fuel poverty. Echoing this, their website makes multiple references to the importance of households having 'adequate lighting' and 'well-lit' homes, as well as sufficient heating. For example, in describing the campaign's objectives the site states that 'The NRFC came into existence in 1975 with the single aim of ensuring that every household is able to afford adequate heat, light and power. Today we are still campaigning to protect the right of all people in the UK to live in a warm, dry and well lit home'. Overall, in both its definitions and wider discourse, the NRFC explicitly and repeatedly represents lighting as an energy-use that matters for fuel poverty concerns.

\section{Discussion}

In this paper, we have drawn on evidence from both policy and national NGOs to examine which energy-uses are included in these groups' portrayal of fuel poverty in the UK. We found both heating and non-heating energy-uses to be incorporated in three of the definitions of fuel poverty that we examined, including the two most recent 'official' policy definitions that are operationalised annually in the generation of fuel poverty statistics. However, the inclusion of non-heating energy-uses in the new LowIncome High-Costs definition is not initially clear, and is only made evident by unpacking the methodology used to generate the UK's annual fuel poverty statistics. Furthermore, in the wider discourse of both policy and NGOs the dominant narrative is that fuel poverty is about a lack of sufficient warmth and space heating. In these portrayals, other energy-uses are rarely mentioned or positioned as significant concerns, and their inclusion in official definitions of fuel poverty is not acknowledged or recognised. The only two evident exceptions to this are, first, the National Right to Fuel Campaign (which frequently presents inadequate lighting as fundamental to the condition of fuel poverty), and, to a lesser extent, the 2001 UK Fuel Poverty Strategy.

Overall, there is some inconsistency and ambiguity in policy and NGO understandings of fuel poverty, but their overriding emphasis is on heating and warmth. This echoes the dominant representation of fuel poverty in the academic literature, and thus there appears to be what Hajer (1995) would term a 'discourse coalition' between these groups. Despite not necessarily agreeing on how the problem should be tackled, and despite having different interests, positions and purposes, these groups all reproduce a particular idea of what fuel poverty 'is' and the energyuses it encapsulates.

But is this situation problematic? In the UK context, space-heating can be argued to be the most important domestic energy service, given the well-documented implications for physical and mental health of living in a cold home (Liddell and Morris, 2010). In terms of taking measures to reduce energy bills and the incidence of fuel poverty, improvements to thermal efficiency of houses are also arguably where the biggest and most cost-effective gains can be made (DECC, 2010). These factors perhaps help explain the dominance of space-heating in UK fuel poverty discourse and research. However, it could be argued that there are good reasons why non-heating energy-uses warrant more substantial and explicit attention in how fuel poverty is talked about, studied and addressed. In particular, there are two areas that have received little focus - perhaps because of an over-emphasis on heating in fuel poverty discourse - but that we believe merit further investigation and debate. 


\section{Quality of life and household coping strategies}

Concerns over fuel poverty are ultimately grounded in whether people are able to access the energy services they need for a minimally-decent quality of life (Bouzarovski and Petrova, 2015; Walker and Day, 2012). Many theories of well-being emphasise that 'quality of life' is multidimensional, going beyond only health to also encompass aspects such as social connection, partaking in meaningful work, and expanding knowledge (Alkire, 2002; Finnis, 1980; Nussbaum, 2011; Wolff and De-Shalit, 2007). Achieving well-being in all of these dimensions is likely to require the use of multiple energy services. Recent research found that members of the UK public deem a number of non-heating energy appliances to now be 'basic necessities' for minimally-decent living standard in the UK (Walker et al., in press). For example, a computer was felt to be essential because of its importance for education and finding a job, whilst lighting was required for, amongst other things, security and social connection (Davis et al., 2015; Walker et al., in press).

Currently, much research on the experience of living in fuel poverty focusses on how people are deprived of the space heating necessary for physical and mental health (e.g. Harrison and Popke, 2011). However, there has been little on how, in adopting 'coping strategies' that attempt to reduce their energy costs, households may also suffer deprivation or 'under-consumption' of other key energy services - to the detriment of their quality of life. There are a few isolated examples of research that documents fuelpoor households reducing their non-heating energy-use in order to manage their bills, some of it outside of the UK context. A World Bank (1999, cited in Buzar, 2007) study in Macedonia found examples of households living without lighting, or even electricity. Households in the US have been found to limit their cooking times in order to save money (Hernández and Bird, 2010), whilst in the UK Lambie-Mumford and Snell (2015) found people who avoided heating their food at all. Anderson et al.'s (2012) quantitative survey found that turning off lights, using less hot water, and having fewer hot meals and drinks were all used as means of 'coping' with high energy costs.

However, these studies do not explore householders' experiences of such behaviours and the potential impact it has on people's wellbeing. Furthermore, beyond these few papers there is little research into such forms of deprivation. We would argue there is significant scope for further investigation by academia, NGOs and DECC, on how and why vulnerable households may suffer 'under-consumption' in non-heating energy-uses, and moreover on how this impacts upon different dimensions of people's quality of life. Furthermore, the potential for non-heating forms of deprivation may increase if new consumer electronics become 'basic necessities' for life in the UK (Davis et al., 2014) and if non-heating energy-uses continue to take up an increasing share of overall household consumption (DECC, 2015a). Furthermore, fuel poverty in the UK is often associated with older people, because of their vulnerability to the health impacts of cold temperatures (Day and Hitchings, 2011). But the notion that several non-heating energy-uses may be 'essential' for achieving well-being (in all its multiple dimensions) brings into view the potential vulnerabilities of a wider section of the population - such as young adults or students. Again, this has implications for further research, and also for policy and NGO thinking on how the 'fuel-poor' might be identified and targeted.

\section{Low-income households and inefficient appliances}

A small amount of research suggests that older or less efficient non-heating technologies - such as fridges, cookers and TVs - are concentrated in low-income or vulnerable households, therefore contributing to fuel poverty problems by putting an upward pressure on people's energy bills. Boardman et al. (1997) found that low- 
income households were more likely to own inefficient or faulty refrigerators and freezers because of their inability to afford alternatives, although a more recent study (using a different methodology) seemingly contradicts this finding (BRE, 2013). Palmer and Terry's (2014) research suggested that people over 65 were more likely to own older (and thus more energy inefficient) cold appliances, tumble dryers, washing machines, and televisions. However, their study did not analyse or discuss inequalities between different income groups. Meanwhile, a survey conducted by DECC (2012) found that people of social grades $D$ (semi and unskilled manual workers) and $E$ (state pensioners, casual or lowest grade workers, unemployed with state benefits only) were least likely to have bought energy efficient appliances, or have the intention of doing so. Inefficient appliances may be also be an issue for those living in the private rental sector - a sector with the highest estimated rates of fuel poverty in the UK (DECC, 2015c) - because such households are likely to face significant constraints on buying new, energy-efficient goods if alternative versions have already been provided by the landlord.

So, although on aggregate the efficiency of many appliances in the UK may have improved in recent years (Palmer and Cooper, 2013) - new fridges, for example, are around 61-65 per cent more efficient in 2014 than in 1990 (DECC, 2015a) - there are reasons to question the extent to which this has been equally felt by different social and income groups. Again, however, the research evidence on such matters is currently slim and inconclusive, and we would thus argue that further investigation is warranted.

In terms of UK fuel poverty mitigation measures, our own previous research has found that, for many years, such policies have predominantly focussed on improving efficiencies related to space heating (insulation and boiler efficiency) - although the Carbon Emission Reduction Target (CERT) supplier obligation that ran until 2012 also included some support for efficient lighting and appliances (Simcock and Walker, 2015). The Energy Company Obligation ('ECO') policies in place since 2013 have dropped such measures, focussing exclusively on insulation and boiler replacements (ibid.). As we have noted, improvements to the thermal efficiency of houses are argued to be the most cost-effective way of significantly reducing household energy bills (DECC, 2010). However, such measures can also suffer from low householder take-up (Rosenow, 2015; Sovacool, 2015) because they are both disruptive and, even with government subsidies, potentially expensive. There may be relatively cheap and costefficient measures to improve the efficiency of appliances and lighting (including new technologies such as LED lightbulbs that have become more mainstream since the end of CERT) that are not currently being explored or pursued, but may help increase the number of people who receive energy efficiency improvements (Rosenow, 2015). As Palmer and Terry (2014) suggest, these measures could potentially be targeted at lowincome households or older people, to help address the possible concentration of inefficient appliances amongst such groups. More research on the relative drawbacks and benefits of such measures compared to improved insulation would also be helpful.

\section{Conclusion}

In conclusion, we argue that there is a strong case for giving non-heating energy-uses more balanced consideration in how fuel poverty is conceptualised by policy, NGOs, and also academia. We have identified two key research and policy areas that we believe warrant further investigation and scrutiny. At the very least, there should be a systematic examination and debate of the pros and cons of developing more active and substantial engagement. 


\section{Notes}

1) Word-counts of this form do have limitations; for example, the usage of certain words can simply reflect writing style, rather than simply the degree of importance given to an issue. We attempted to minimise the impact of this limitation in two ways: by, as noted above, using multiple synonyms to search for a single energy use, and also by combining this quantitative analysis with a qualitative analysis of discourse.

2) National Energy Action (NEA) is a national charity that seeks to 'end fuel poverty.' It undertakes a range of activities including research, campaigning and energy efficiency projects.

\section{Acknowledgements}

We would like to thank John Henderson at BRE and Jack Carrington at the Association for the Conservation of Energy for helping us to unpack the fuel poverty modelling process. The research in this paper was undertaken in Lancaster University's DEMAND Centre, which received funding from the Engineering and Physical Sciences Research Council (grant number EP/K011723/1) as part of the RCUK Energy Programme and from EDF as part of the R\&D ECLEER Programme.

* Corresponding address: Neil Simcock, School of Environment, Education and Development, University of Manchester. Email: n.simcock@outlook.com

\section{References}

Alkire, S. (2002) Dimensions of human development. World Development, 30, 2, 181205.

Anderson, W., White, V. and Finney, A. (2012) Coping with low incomes and cold homes. Energy Policy, 49, 40-52.

Boardman, B. (1991) Fuel poverty: from cold homes to affordable warmth. London: Bellhaven.

Boardman, B. (2010) Fixing Fuel Poverty: Challenges and Solutions. London: Earthscan: 113.

Boardman, B., Lane, K., Hinnells, M., Banks, N., Milne, G., Goodwin, A. and Fawcett, T. (1997) Transforming the UK Cold Market. Oxford: DECADE Project, Environmental Change Institute, University of Oxford.

Bouzarovski, S. and Petrova, S. (2015) A global perspective on domestic energy deprivation: Overcoming the energy poverty-fuel poverty binary. Energy Research and Social Science, 10, 31-40.

Bradshaw, J. and Harris, T. (1983) Introduction. In: Bradshaw and Harris (eds.) Energy and Social Policy. London: Routledge and Keegan Paul.

Bradshaw, J., Middleton, S., Davis, A., Oldfield, N., Smith, N., Cusworth, L. and Williams, J. (2008) A minimum income standard for Britain. York: Joseph Rowntree Foundation.

BRE (2013) Energy Follow-up Survey, 2011: Report 9: Domestic appliances, cooking \& cooling equipment. Watford: BRE.

Buzar, S. (2007) Energy Poverty in Eastern Europe: Hidden Geographies of Deprivation. Aldershot: Ashgate. 
Christman, B. and Russell, H. (2016) Readjusting the Political Thermostat: Fuel Poverty and Human Rights in the UK. The Journal of Human Rights in the Commonwealth, $2,2,14-31$.

Davis, A. et al. (2014) A minimum income standard for the UK in 2014. York: Joseph Rowntree Foundation.

Davis, A., Hirsch, D., Padley, M. and Marshall, L. (2015) How much is enough? Reaching consensus on minimum household needs. Loughborough: Centre for Research in Social Policy, Loughborough University.

Day, R. and Walker, G. (2014) Justice and energy use within the capabilities framework. Paper presented at the Justice, Governance and Energy Services workshop, September 2014, Paris.

Day, R. and Hitchings, R. (2011) 'Only old lades would do that': age stigma and older people's strategies for dealing with winter cold. Health \& Place, 17, 4, 885-894.

Department of Energy and Climate Change (2010) Consultation on the Role of Appliances and Consumer Electronics in CERT. London: DECC.

Department of Energy and Climate Change (2012) Household Electricity Survey. London: DECC.

Department of Energy and Climate Change (2013a) 'Fuel poverty statistics'. Available at: https://www.gov.uk/government/collections/fuel-poverty-statistics [Accessed: 16/1/2015]

Department of Energy and Climate Change (2013b) Fuel Poverty: a Framework for Future Action. London: DECC.

Department of Energy and Climate Change (2014) The Fuel Poverty Statistics Methodology and User Manual. London: DECC.

Department of Energy and Climate Change (2015a) Energy Consumption in the UK (2015). London: DECC.

Department of Energy and Climate Change (2015b) Cutting the cost of keeping warm: A new fuel poverty strategy for England. London: DECC.

Department of Energy and Climate Change (2015c) Annual Fuel Poverty Statistics, 2015. London: DECC.

Defra and DTI. (2001) The UK Fuel Poverty Strategy. London: Defra/DTI.

Dubois, U. (2012) From targeting to implementation: The role of identification of fuel poor households. Energy Policy, 49, 107-115.

Energy Saving Trust (2011) The elephant in the living room: how our appliances and gadgets are trampling the green dream. London: Energy Saving Trust.

Entman, R. (1993) Framing: Toward clarification of a fractured paradigm. Journal of Communication, 43, 4, 51-58.

Fairclough, N. (1992) Discourse and Social Change. Cambridge: Policy Press.

Finnis, J. (1980) Natural Law and Natural Rights. Oxford: Clarendon Press.

Hajer, M. (1995) The politics of environmental discourse: ecological modernization and the policy process. Oxford: Clarendon Press.

Harrison, C. and Popke, J. (2011) 'Because You Got to Have Heat': The Networked Assemblage of Energy Poverty in Eastern North Carolina. Annals of the Association of American Geographers, 101, 949-961.

Henderson, J. and Hart, J. (2013) BREDEM 2012 - A technical description of the BRE Domestic Energy Model. Watford: BRE.

Hernández, D. and Bird, S. (2010) Energy Burden and the Need for Integrated Low Income Housing and Energy Policy. Poverty and Public Policy, 2, 5-25.

Hills, J. (2011) Fuel Poverty - The problem and its measurement: Interim Report of the Fuel Poverty Review. London: Centre for Analysis of Social Exclusion, London School of Economics.

Hills, J. (2012) Getting the Measure of Fuel Poverty: Final Report of the Fuel Poverty Review. London: Centre for Analysis of Social Exclusion, London School of Economics. 
Lambie-Mumford, H. and Snell, C. (2015) Heat or Eat: Food and Austerity in Rural England'. Final Report July 2015. Sheffield/York: University of Sheffield/ University of York.

Liddell, C. and Morris, C. (2010) Fuel poverty and human health: A review of recent evidence. Energy Policy, 38, 2987-2997.

Middlemiss, L. and Gillard, R. (2015) Fuel poverty from the bottom-up: Characterising household energy vulnerability through the lived experience of the fuel poor. Energy Research \& Social Science, 6, 146-154.

Moore, R. (2012) Definitions of fuel poverty: Implications for policy. Energy Policy, 49, 19-26.

Nussbaum, M. (2011) Creating Capabilities: The Human Development Approach. London: Belknap Press.

Ormandy, D. and Ezratty, V. (2012) Health and thermal comfort: From WHO guidance to housing strategies. Energy Policy, 49, 116-121.

Palmer, J. and Cooper, I. (2013) United Kingdom housing energy fact file. London: DECC.

Palmer, J. and Terry, N. (2014) Powering the Nation 2: Electricity use in homes, and how to reduce it. London: DECC and DEFRA.

Roberts, S. (2008) Energy, equity and the future of the fuel poor. Energy Policy, 36, 12, 4471-4474.

Rosenow, J. (2015) CIED gives evidence to the ECC on Home Energy Efficiency and demand reduction. Available at: https://blogs.sussex.ac.uk/sussexenergy group/2015/12/17/cied-evidence-to-the-ecc-on-home-energy-efficiency-anddemand-reduction/ [Accessed: 17/12/2015]

Simcock, N. and Walker, G. (2015) Fuel Poverty Policy and Non-Heating Energy Uses. DEMAND Centre Working Paper 16. Lancaster: DEMAND Centre.

Sovacool, B.K. (2015) Fuel poverty, affordability, and energy justice in England: Policy insights from the Warm Front Program. Energy, 93, 361-371.

Viggers, H., Howden-Chapman, P., Ingham, T., Chapman, R., Pene, G., Davies, C., Currie, A., Pierse, N., Wilson, H., Zhang, J., Baker, M. and Crane, J. (2013) Warm homes for older people: aims and methods of a randomised community-based trial for people with COPD. BMC Public Health, 13, 176-188.

Walker, G. and Day, R. (2012) Fuel Poverty as injustice: integrating distribution, recognition and procedure in the struggle for affordable warmth. Energy Policy, 49, 69-75.

Walker, G., Day, R. and Simcock, N. (2015) What counts as "required" energy? Principles of need in modelling the extent of fuel poverty. DEMAND Centre Research Insight 5. Lancaster: DEMAND Centre. Available at: http://www.demand.ac.uk/writing-talking-images/research-insights/

Walker, G., Simcock, N. and Day, R. (in press) Necessary energy uses and a minimum standard of living in the United Kingdom: energy justice or escalating expectations? Energy Research \& Social Science.

Wolff, J. and de-Shalit, A. (2007) Disadvantage. Oxford: OUP. 